\title{
The River of Conquest: Three Stories of the Tennessee River
}

\section{Torben Huus Larsen}

Odense, Denmark

\begin{abstract}
The essay outlines the narrative of conquest as an integral part of the Tennessee River's history. Looking at three early versions of that narrative, including the Donelson expedition down the river in the winter of 1779, the forced removal of the Cherokees in the early 19 th Century, and the Civil War battle of Shiloh, the essay demonstrates how the river was inscribed in a tale of human domination over other people, cultures, and even over the river itself, and this was long before the Tennessee Valley Authority dammed the river and conquered its turbulent waters.
\end{abstract}

Keywords: American Studies - Environmental Studies - The Tennessee River Donelson expedition - Cherokee - forced relocation - American Civil War Shiloh-Tennessee Valley Authority

The narrative of conquest is an integrated part of the Tennessee River's history. It is far from the only narrative connected with the Tennessee, but it is one of the most potent. From John Donelson's journey down the river in 1779 to the environmental conquest of the river by Roosevelt's Tennessee Valley Authority (TVA), the waterway has continually been inscribed in a complex tale of attempted human domination at times exerted over other peoples and cultures by way of the river, at times over the river itself.

The narrative of conquest was inscribed upon the banks of the Tennessee long before white settlement transformed the area. The Cherokee, Creek, and Chickasaw tribes used the river for matters as diverse as marriage and war, and navigating its deadly currents often proved a battle in itself. Yet as the influx of white settlers into the Tennessee Valley 
increased in the late 18 th century the story of conquest became the increasingly dominant narrative. By looking at three different versions of this narrative (the Donelson journey, the relocation of the Cherokees, and the battle of Shiloh) this essay will outline some of the narrative heritage that has become such a central part of the river's history.

The Donelson Expedition

The Indian peoples of the Tennessee Valley were left largely undisturbed by their European neighbors until the end of the 18 th century. Up until then the French had monopolized a great deal of the trade and navigation on the Mississippi River but although they were interested in the Indian trade of the Tennessee Valley, the natural obstacles presented by Muscle Shoals, a formidable sixty mile stretch of rapids, largely hindered their passage up the Tennessee River. In the same way the Appalachian Mountains of eastern Tennessee served as a natural barrier to the western expansion of the English colonies in Virginia and North Carolina, and by the 1760 s there were still only few travelers in the region.

By the 1770 s, however, rumors of the Tennessee Valley's fertile alluvial lands spread rapidly among the settlers of Virginia and North Carolina, and a steady stream of traders and scouts began entering the valley by rivers and overland routes. The interest in purchasing the cheap and fertile lands along the Tennessee and the Cumberland rivers was great, and officials from North Carolina, as well as representatives from private companies such as the newly founded Transylvania Company, constantly looked to extend the boundaries of their settlements.

Naturally the many trespasses on to their territory proved greatly distressing to the Cherokees, and at the Treaty of Sycamore Shoals in 1775 a fraction of warriors broke away from the Cherokee Nation. The Chickamaugas, as they called themselves, declared war on all settlers in the area, and as the group left the Sycamore Shoals meeting, their young, muscular, and pockmarked leader, Dragging Canoe, warned the representatives of the Transylvania Company that although they had "bought a fair land" they would "find its settlement dark and bloody" (Govan 27).

The Chickamaugas kept their promise and by early 1779 the governments of Virginia and North Carolina were drained economically and 
psychologically by the many attacks on American settlements in the Tennessee and Cumberland valleys (as well as by the ongoing revolutionary war against Britain). Finally, officials from the two states decided to launch a large-scale counter offensive. A party of five hundred men, a combination of the revolutionary armies of Colonel Evan Shelby and Colonel John Montgomery, met at the mouth of Big Creek on the Holston. Ironically, the strike upon the Chickamaugas relied upon the soldiers' ability to imitate Indian woodcrafts. They spent ten days making Indian style canoes and pirogues from the trees of the surrounding forest in an effort to speedily navigate the river and maintain the element of surprise in the attack; and the plan worked. Taking advantage of the swift current created by the spring tide, so "rapid was the descent of this first naval armament down the river, as to take the enemy completely by surprise" (Ramsey 187). In fact, the raid was such a surprise that although the number of warriors present in the town of Chickamauga was equal to the number of soldiers and could easily have put up a fight, at the sight of the soldiers everyone in town simply turned and fled into the mountains. Shelby and Montgomery destroyed no less than eleven towns during the raid, but the Chickamaugas merely escaped farther down river, set up new towns and continued their raids against white settlements.

In spite of the Chickamaugas' attacks the settlement of the Tennessee Valley continued. Permanent settlements were already being planned on the banks of the Cumberland River (the area that had been opened up to settlement by the Treaty at Sycamore Shoals), and in December of 1779 Colonel John Donelson embarked on a four month journey that would eventually take him down the Tennessee, up the Ohio to the mouth of the Cumberland River, and up the Cumberland to the new settlements at the site of Nashborough (present-day Nashville). There he was to rendezvous with James Robertson, who earlier that same year had led the most experienced hunters and Indian fighters of the expedition to the settlement by an overland route known as the Kentucky Trace. Donelson's fleet of flatboats would then bring the less experienced and older men, as well as the women and children, and as many household goods as possible.

Although Donelson's trip was perceived to be the safer of the two routes, his task was by no means easy or desirable. The winter of 1779 "was one of the coldest ever known in the Tennessee country.... a season when the hardiest pioneer might have wished himself a bear, to curl 
inside a hollow tree and suck his paw" (Davidson 1991, 149). Indeed, in light of the weather, the dangerous waters the party was to travel, and the context of Tennessee's troublesome and bloody settlement, Donelson's voyage became one of multiple conquests, settling a heathen Indian Territory in the name of America as well as Christianity, while claiming a human triumph over nature.

The party embarked on the journey on December 22 and entered the Tennessee proper on March 4. Already in Indian Territory the party was forced to post guards in the event of an attack. Three days later, on March 7 , the wind and rain forced the fleet to make camp at the site of one the former Chickamauga towns which had been deserted during the campaign of Shelby and Montgomery less than a year before. To the party the encounter with the Chickamauga ghost-town must have served as a reminder of the military campaign itself, but it also suggested how much of the river that was already under American control.

After leaving the deserted town the party soon came upon the new Chickamauga towns, and in his journal Donelson notes how on several occasions the party was attacked by the hostile Indians. In spite of continued attempts to lure the expedition into town by friendly words and presents, the Donelson-party wisely kept to the opposite shore away from the villages. Still, several members of the expedition were killed in these attacks, including 28 passengers of one flatboat that had purposefully been trailing the rest of the fleet due to an epidemic of smallpox. Hearing the screams and the sound of gunfire as the Indians fell upon this last boat, the expedition could only continue moving down the river. The swiftness of the stream that had carried the party past the Chickamauga towns too fast for the Indians to launch any real coordinated assault, also prevented any turning back to help the doomed boat. As Davidson grimly comments, the expedition's only solace must have been the certainty "that the smallpox would wreak revenge for them; and tradition says that it did" (Davidson 1991, 160).

On March 12, the company finally reached Muscle Shoals. The party was anxious to avoid crossing the dangerous shoals, and as it turns out Donelson had made a deal with James Robertson, that he was to have left a sign if it was in any way possible for the fleet to proceed over land rather than attempt to cross the shoals. But to Donelson's distress no such sign was to be found, and because the party believed that they were still 
in danger from the Chickamaugas, it was decided that the safer route was down the river and over the shoals which

had a dreadful appearance to those who had never seen them before. The water being high made a terrible roaring, which could be heard at some distance among the driftwood heaped frightfully upon the points of the islands, the current running in every possible direction. Here we did not know how soon we should be dashed to pieces, and all our troubles ended at once. Our boats frequently dragged on the bottom, and appeared constantly in danger of striking. They warped as much as in a rough sea. (Donelson 200)

Donelson's view of the shoals would soon change however. The spring tide carried the party across the approximately sixty miles of shoals in only three short hours. Had the water been at a lower stage their passage of Muscle Shoals would have been nearly impossible, and undoubtedly had a more tragic outcome, but from Donelson's perspective they had conquered yet another part of the Tennessee, and his description of the dangerous rapids suddenly changed as he pondered the length of "this wonderful shoal" (Donelson 201). Clearly Donelson's success in passing the most dangerous and difficult obstacle on the river allowed him, as narrator, to reduce Muscle Shoals to a mere part of the scenic river landscape. Rhetorically and psychologically, his journal reflects a transformation from inferiority to superiority that casts his feat in terms of a conquest. To Donelson the party tamed the river as the journey progressed.

Only three days later the party reached the Ohio River. The situation must have looked depressing to the exhausted party as high waters and a swift current made an ascend to the mouth of the Cumberland almost impossible. Tired and starved, the party labored against the current of the Ohio for nine days before reaching the mouth of the Cumberland, a mere twelve miles above the Tennessee. Once on the Cumberland, however, the current slowed down and the rest of the trip proved relatively easy. On April 23 they arrived at the first settlements and the very next day reached their destination at the Big Salt Lick.

Donelson's journal is a narrative of conquest on several levels. Aside from the political and historical context of Tennessee's settlement, the taming of the wilderness, and Donelson's personal discourse of conquest and bravery, the journal also describes a victory of Christianity over a heathen landscape and its peoples. As the title of the journal suggests, the voyage served a divine purpose by settling a heathen country in God's 
name, but Donelson also evokes God's protection during the journey. For example, he makes it clear that the party was able to pass Muscle Shoals only "by the hand of Providence" (Donelson 201). Thus, the voyage becomes inscribed in the larger religious and cultural narrative of civilizing and converting the wilderness. In Donelson's narrative, God claims control over Muscle Shoals in order to allow his pilgrims to pass safely, overruling an Indian landscape complete with its own history, mythology, and deities. Through Donelson's voyage, Christianity seemingly conquers the Indian river banishing its wilderness qualities and transforming it into part of civilized and Christianized America.

\section{The River of Relocation}

By the early 19th century the native cultures of the Tennessee Valley had largely succumbed to the pressure of white migration. But even though the territory held by the Indians was rapidly diminishing, the Governors of Georgia and Tennessee continued to pressure the federal government to initiate a program of relocation which the states had been promised in 1802. Although most Cherokees had been quick to adopt a strategy of assimilation in an effort to establish themselves as equals within American society, they balanced on the brink of being forced out of their homelands; and just as the settlement of the Tennessee Valley, the coming removal of the Indians followed the winding waters of the Tennessee River system.

Prior to 1820 , individual Cherokee families had begun to move in order to find refuge and isolation from the expanding American society, and boats full of Indian emigrants became a more common sight during the 1820 s. The emigrants often travelled via the rivers going down first the Tennessee and the Ohio, and finally the Mississippi River to get to present-day Arkansas. In 1829, for example, seventy keel- and flatboats were delivered to the Cherokees' agent, and over the course of the next two years all of these boats left for the trans-Mississippi West. Most of the emigrants left from Gunter's Landing from where they descended the Tennessee, the Ohio, and the Mississippi to the mouth of White River. From there a steamboat transported the Cherokees up the Arkansas River to their new home in Oklahoma.

Yet there seemed to be a pattern to these voluntary relocations. 
According to Grant Foreman, an observer noted that on one boat, out of nearly 200 passengers only "few of them looked like Indians as most of them were intermarried whites with their Indian families and negro slaves" (Foreman 231). The picture was the same in 1832 as a party of 380 Cherokees were getting ready to leave. Out of the emigrants, 108 were black, forty were white, and the remaining majority was of mixed blood. Indeed, only very few full-blooded Indians seem to have signed up for the removal at all.

In an attempt to enrol as many Cherokee families as possible for relocation, the federal government formed commissions who were to persuade, assist and direct the emigrants. However, enrolment often had to be realized by offering the poor Indians annuities for signing up, and filling the boats was still slow work because many tribal leaders threatened anyone who signed up with physical punishment. Consequently, although poverty and rough winters guaranteed the enrolment of many suffering and poor Cherokees, when it became time to relocate, few came to the Cherokee Agency in Calhoun, Tennessee. Most of those who signed up had done so merely to receive the economic benefits that were included in the deal. The few emigrants that did arrive at the Cherokee Agency were housed in primitive huts along the Hiwassee River. There they could find some shelter from the weather, but conditions were crude and did not improve once the journey started. The relatively open flatboats did not afford much shelter from the cold wind and rain, and in some cases the boats had not even been outfitted with a fireplace or an oven. As a result many of the emigrants fell ill, some died, and yet others deserted during the trip, and as stories of the miserable conditions spread to those remaining behind, it became increasingly difficult to get anyone to sign up.

The hardships of one journey are recorded in the journal of physician Dr. C. Lillybridge from New York, who attended a party of Cherokee emigrants on their journey down the Tennessee in March of 1837. The journal of this trip gives an excellent example of what these relocations were like, and Lillybridge's account seems remarkable only in the sense that not a single passenger died on the trip. Central in the narrative are the diseases that tormented the emigrants, the many locals who attempted to peddle their whisky to the Indians, and the general disrespect with which those who had planned the relocation treated the Cherokees. 
Lillybridge's party embarked from Ross' Landing on March 3, traveling a mere five miles on the first day. Already at this early point, however, Lillybridge commented on the poor shelter which the boats provided the emigrants. "Night cold with high winds. Boats too open for the comfort of the emigrants" (Foreman "Journey," 234). In the cold and damp March weather many of the immigrants soon became ill with the common cold, fever, and diarrhea. The lack of shelter on the boats indicated the lack of concern with which the relocation had been planned, and in one instance, having arrived in Decatur from where the emigrants were to be transported across Muscle Shoals by train, an entire day was spent "setting upon the open Carrs, waiting the arrival of the locomotive, the weather having become very cold" (Foreman "Journey," 236). When the order was finally given that the train would not leave until the next morning, Lillybridge "was not a little surprised to find that no one had made it his business to aid and direct the Indians, where they could lie for the night" (Foreman "Journey," 236).

When the party reached Tuscumbia on the other side of the shoals, the second part of the river journey began and once again Lillybridge found the boats to be below standard. Travelling upon the steamboat Newark, as well as in a number of keelboats in tow, the boats were "entirely too limited in room and conveniences for the accommodation of the party. The Keel Boats are without stoves or fires in them ... \& present to those accustomed...to many of the comforts of civilized life, rather a revolting spectacle" (Foreman "Journey," 239). Reaching Oklahoma on March 28 most were glad to be off the boats, although the new landscapes of that area must have seemed both strange and frightening to many of the emigrants.

Although little thought had been given to the welfare of the families who signed up for voluntary relocation, nothing compared to the forced removal of the Cherokees that took place in the summer of 1838. By early 1838 only 2,000 Cherokees had relocated, leaving nearly 17,000 Indians who were still living in the East. Frustrated with the pace of voluntary relocation the government warned the Cherokees, reminding them that according to the Treaty at New Echota they had ceded all their remaining lands and were to be ready for relocation on May 23 at the latest. The treaty had been signed by a small and unrepresentative group of pro-relocation Cherokees who called themselves the Treaty Party. 
They had secretly met with representatives of the United States in 1835 reaching an agreement whereby all Cherokee lands were sold for 5 million dollars and some land rights in Oklahoma. In spite of the fact that an overwhelming majority of the Cherokee Nation claimed no knowledge of the treaty and protested that the Treaty Party had no mandate to negotiate on their behalf, the treaty proved the solution for everything many Americans had hoped for and was quickly ratified by the Senate.

In May 1838 armed soldiers began rounding up Cherokee individuals and families at gunpoint, leading them to departure camps. Families "at dinner were startled by the sudden gleam of bayonets in the doorway and rose to be driven with blows and oaths along the weary miles of trail that led to the stockades.... in many cases, on turning for one last look ... they saw their homes in flames, fired by the lawless rabble that followed on the heels of the soldiers to loot and pillage" (Mooney 130). As families were rushed to the nearest camps, they often became separated in the process and were shipped off individually, not knowing whether they would ever see their parents, children, or spouses again.

When nearly all 17,000 Cherokees had been gathered in the stockades, they were divided up into smaller groups in which they were to travel. In early June three such parties of around 2,800 individuals were shipped down the river. The first party, consisting of approximately 800 people, left on June 6 under the supervision of Lieutenant Edward Deas. On June 15 the next party followed carrying 875 emigrants. Deas was an experienced officer in dealing with emigrants, and he had traveled the Tennessee before. In 1835 he had supervised the emigration of a party of Creek Indians from Georgia and Alabama to west of the Mississippi. But although experienced in matters of Indian removal, Deas nevertheless made a mistake when, due to the confusion on the overcrowded boat decks, he did not count the Cherokee emigrants until they reached Tuscumbia. At this point he had only 489 left, the rest had either died from disease or by accident, or simply deserted in order to return home.

According to Satz, the "mortality rate of the first 3,000 captive Indians who departed under military supervision was horribly high due to disease, exposure, fatigue, and other hardships of travel" (Satz 93). Seeing these tragedies of the forced relocation, the Cherokee leaders pleaded with the government to allow them to conduct their own removal. The wish was granted by President Van Buren and by October 1838 the 
remaining thousands of Cherokees moved westward by an overland route on what has been remembered as the Trail of Tears. Almost one third of the 17,000 Cherokees had died as a result of the hardships of travel or the lacking treatment in the camps. The conquest of the Cherokee lands was over and only the few that had managed to escape during the relocation remained in the area they considered their home.

Shiloh and the Defeat of a Southern River

As the Civil War began in 1861, the Tennessee undoubtedly was far from most people's minds. Yet, winding its way into the very heart of the Confederacy, the Tennessee soon became one of the war's most contested terrains. A native born Kentuckian, and an old flatboat man himself, President Abraham Lincoln was acutely aware of the importance of controlling the Cumberland and the Tennessee rivers when he supposedly stated that while hoping "to have God on his side, he must have Kentucky" (McPherson 284).

The Confederates were also aware of the dangerous scenario that the Tennessee might be turned into "a Union highway into the Deep South" (McPherson 397). Yet the defense of the river was weak, and in just one month (during February of 1862) the Union forces took control of both the lower Tennessee and the Cumberland River. With the loss of the Cumberland River Nashville was suddenly open to attack, and via the Tennessee the Union forces could move in on the city of Columbus on the Mississippi River from behind, or attack the town of Corinth, Tennessee, one of the main railroad centers of the South.

By March General Halleck decided to make an attempt at gaining control over Corinth and cut the lines of the southern railroad. He ordered Grant to Pittsburg Landing on the Tennessee River with his 40,000 men, where General Buell shortly after was to join him with an additional 35,000 troops. In total, Grant had six divisions under his command. Two of these divisions had been placed ahead in the unlikely event of an attack, and one division under the command of General Lew Wallace had been stationed some miles north of the other camps to guard the depots. Confident that no attack would come until he himself initiated it, Grant himself had set up camp at Pittsburg Landing with the three remaining divisions. However, a Confederate joint force consisting of the armies of 
General Albert Sidney Johnston and the flamboyant General Beauregard waited at Corinth, and having foreseen Halleck's move they planned to strike Grant before Buell had time to reach Pittsburg Landing.

The Confederate attack was planned for April 4 and called for a long march to the battleground. But heavy rains and the great number of inexperienced soldiers caused almost two days of delay, as troops got lost in the woods and wagons got stuck on the muddy roads. Furthermore, Beauregard was certain that any moment of surprise had been ruined by soldiers firing their rifles into the air in order to check their wet ammunition. But Grant's overconfidence and the fact that northern troops also tested their ammunition by firing into the air meant that when thousands of screaming rebels burst out of the woods on the morning of April 6, the Union troops were not ready for them.

Grant who heard the attack as he was eating breakfast at Savannah, a couple of miles down river from Pittsburg Landing, promptly steamed up to the battleground, but by then there was little he could do to turn the battle around. After ten hours of fighting, a total of 2,000 soldiers had died, including the Confederate General Johnston who "was struck in the thigh by a Minié ball, and, not having a surgeon in attendance, bled to death on the field" (Davidson 1992). Recognizing that his troops had no more to give, Beauregard called off a final attack and camped for the night. There was no question that the Confederacy had won the day, taking many of the positions formerly held by the Union army, and as the northern troops were driven back many saw the muddy waters of the Tennessee as their only rescue. However, by nightfall Buell had arrived with fresh troops that were being ferried over the Tennessee, and the dark gave the Union soldiers a chance to reorganize.

The second day began with another surprise attack, but this time it was Grant who had ordered it, and the momentum gave the Union troops the advantage. Furthermore, the reinforcements brought by Buell meant that Grant had more men and fresh troops, and in general the northern army was better supplied than its southern counterpart. By that afternoon the Confederate army had been driven back to the point of the original attack, and the death toll was staggering. Both armies were exhausted from the many hours of fighting, and ultimately Beauregard gave the order to retreat in order to save what was left of his army. No real advances had been made during the fighting, as the Union troops had merely recon- 
quered what they had lost on the first day. But the magnitude of the battle with 20,000 casualties, as well as the size of the Union fleet unparalleled in American history, testifies to the strategic importance of the Tennessee. No less than fourteen gunboats, 153 transport boats, and twenty steamboats took part in the battle of Shiloh, and it would not be the last battle for control of the Tennessee Valley; ahead lay such bloody confrontations as the battle of Chickamauga and the long fight over Chattanooga.

The conquest of the Tennessee River was essential to winning the war, but the conquest of the river also became a symbolic conversion of a southern landscape in Ambrose Bierce's short story "What I saw of Shiloh." Told from a northern point of view, the story subtly uses the conquest of the Tennessee River as a subplot and background to the main narrative. In Bierce's story, the river, running under "sylvan arches heavily draped with Spanish moss" (Bierce 3), is part of a uniquely southern landscape and as such it is hurt by the intrusion of the Union gunboats. As Bierce writes, "when they let off their big guns there was a conflagration. The river shuddered in its banks, and hurried on, bloody, wounded, terrified!" (Bierce 5). The inferred violence of the gunboats hurts the river as an embodiment of the South, and by taming the river the South is ultimately defeated. The conquest of the river proves complete, as arriving Union troops find safety beneath its tall banks, while fleeing northern soldiers escape the horrors of the battlefield by blindly plunging into the sanctuary of the river. Furthermore, the narrative transformation of the river from a hostile environment into Union territory coincides with the Union troops gaining the advantage on the battlefield. Thus the conquest of the Tennessee as a Southern landscape becomes an integral part of Bierce's war narrative of the battle of Shiloh.

Mankind has always narrated the environment through actions and representations, and the centrality of conquest as a theme in American history is not new. As such it is no surprise that the Tennessee River has been inscribed in a narrative of conquest formed by the ways in which the river has been used and represented. Although the Indian tribes of the Tennessee Valley initiated the narrative of conquest long before European settlers arrived, by using the river in ongoing wars against neighboring tribes, it was not until the influx of white settlers into the area in the late 18 th century that the narrative of conquest became as dominant a 
part of the Tennessee River's history as it is today. By looking at three versions of this narrative, John Donelson's journey into Indian Territory to help found the settlement of Nashborough, the extensive use of the Tennessee for relocating the Indian tribes of the region, and the river's role in the battle of Shiloh, this essay has outlined the connection between the idea of conquest and one of the region's foremost natural resources; a connection that in the 1930 s led to the definite defeat of the wild river when Roosevelt's Tennessee Valley Authority dammed it, turned it into a series of controllable and docile lakes, and harnessed its power for hydroelectric purposes.

\section{Works Cited}

Ambrose Bierce. "What I saw of Shiloh." In Civil War Stories. Ed. Candace Ward. Dover Publications, 1994.

Davidson, Donald. The Tennessee Vol. 1, The Old River: Frontier to Secession. 1946. J. S. Sanders \& Company, 1991.

Davidson, Donald. The Tennessee Vol. 2, The New River: Civil War to TVA. 1948. J. S. Sanders \& Company, 1992.

Donelson, John. Journal of a Voyage, intended by God's permission, in the good boat Adventure, from Fort Patrick Henry on Holston River, to the French Salt Springs on Cumberland River, kept by John Donelson. In The Annals of Tennessee to the End of the Eighteenth Century. J. G. M. Ramsey. The Overmountain Press, 1999.

Foreman, Grant. Indian Removal: The Emigration of the Five Civilized Tribes of Indians. 1932. Norman: University of Oklahoma Press, 1972.

Foreman, Grant. "Journey of a Party of Cherokee Emigrants." The Mississippi Valley Historical Review, 18/2 (1931), 232-45.

Govan, Gilbert E. \& James W. Livingood. The Chattanooga Country, 1540-1976: From Tomahawks to TVA. Knoxville: University of Tennessee Press, 1977.

McPherson, James M. Battle Cry of Freedom: The American Civil War. 1985. Penguin Books, 1990.

Mooney, James. Myths of the Cherokee. Dover Publications, 1995.

Ramsey, J.G.M. The Annals of Tennessee to the End of the Eighteenth Century. 1853. The Overmountain Press, 1999.

Satz, Ronald N. Tennessee's Indian Peoples: From White Contact to Removal, 1540-1840. Knoxville: University of Tennessee Press, 2001. 